\title{
Effects of low temperatures on the first development stages and protein composition of two genotypes of Lupinus albus $L$
}

\author{
P Villais, A Kersulec, J Citharel \\ Laboratoire de Physiologie Végétale, Université de Rennes l, 35042 Rennes Cedex, France
}

(Received 28 February 1991; accepted 21 June 1991)

\begin{abstract}
Summary - Some characteristics related to low temperature effects were studied in 2 white lupin genotypes: a spring one (Lutop) and a winter one (LA99). These characteristics concerned seed imbibition and germination and protein metabolism in young plants. Low temperatures influenced protein metabolism: they stimulated synthesis of some proteins, suppressed synthesis of others and had no apparent effect on some others. The spring genotype showed more important alterations in the young, growing organs (root tips, leaves, shoot apices) whereas, in the winter form, alterations were more important in fully developed leaves. The most hydrophilic proteins seemed to be the most concerned by these alterations.
\end{abstract}

protein analysis / CLHP / genetic expression

Résumé - Effets des basses températures sur les premiers stades de développement et la composition protéique de 2 génotypes de Lupinus albus L. L'étude de deux génotypes du Lupin blanc, l'un "de printemps» (Lutop), l'autre "d'hiver" (LA99) a permis de mettre en évidence certains effets des basses températures sur l'imbibition des graines, leur germination et le métabolisme protéique des jeunes plants. À basse température, l'inhibition et la germination ne diffèrent pas de façon importante pour les deux variétés (fig 1 et 2). Toutefois, une faible imbibition de la germination (de l'ordre de 5\%) se manifeste pour la variété Lutop placée à $5{ }^{\circ} \mathrm{C}$ dès le début de l'apport d'eau. L'analyse des protéines indique que l'action du froid se traduit par une activation, une inhibition ou n'a aucun effet, sur la synthèse de différents polypeptides. Pour la variété de printemps, ces variations sont nettement plus marquées au niveau des organes jeunes en croissance (racines (fig 3 et 4), feuilles (fig 6), apex caulinaires (fig 5)). Au contraire, pour la forme d'hiver, elles sont plus importantes au niveau des feuilles complètement formées (fig 6). Les protéines les plus hydrophiles semblent plus affectées par ces modifications. Les réponses des deux génotypes de lupin blanc à l'action des basses températures sur la composition en protéines indiquent donc des modifications du métabolisme des protéines. Ces modifications dépendent de la variété et de chaque organe étudié. De plus, elles traduisent une résistance (ou une adaptabilité) relativement importante du génotype de printemps à l'action du froid.

analyse des protéines / CLHP / expression génétique

\section{INTRODUCTION}

Crop plants are submitted to numerous environmental stresses (salinity, drought, extreme temperatures...). These constraints are significant limiting factors in agricultural productivity, and can cause decreased yields or plant death. But plants possess a high degree of metabolic plasticity. So, chilling sensitive species become more resistant to freezing temperatures when submitted first to moderate stress conditions (cold hardening or cold acclimation).

Cold acclimation is a complex response involving physical and biochemical changes. Variations in protein and fatty acid composition of membranes, as in free sugar and soluble protein content are known to occur in plant cells exposed to low temperatures (Steponkus, 1981; Graham and Patterson, 1982; Guy, 1990). Photosynthesis is greatly affected (Berry and Bjorkman, 1980; Levitt, 1980; Berry and Raison, 1981; Steponkus, 1981; Carter and Brenner, 1985; Herner, 1986; Markhart, 1986). But the molecular basis for cold hardening is not yet understood and the cause and effect relationships remain to be established.

An important component in the adaptation of plants to low temperatures is change in the syn- 
thesis of proteins (Sarhan and D'Aoust, 1975; Fowler et al, 1977; Kacperska-Palacz et al, 1977; Chen et al, 1983; Cloutier, 1983; Guy, 1990). Some specific mRNA accumulated at low temperature while others decreased (MezaBasso et al, 1986; Gilmour et al, 1988; Mohapatra et al, 1988, 1989; Wu et al, 1988). Thus, cold hardening might involve change in gene expression (Weiser, 1970; Berry and Raison, 1981; Sarhan and Chevrier, 1985; Mohapatra et al, 1989). Cold acclimation of some perennial plants may require both transcriptional activation of genes and the synthesis of new proteins (Weiser, 1970; Voinikov et al, 1989; Lin et al, 1990). In order to understand the molecular basis of plant adaptation to low temperature, it is important to know if the protein-synthesizing possibilities of the cells change following a genotypic adaptation. However, very little is known about the nature of cold regulated genes. The stress protein synthesis in plant under the influence of low temperature has been poorly studied. No information exists about their identity and their function.

In the present study, we compared protein composition of roots and leaves from two varieties of white lupin, a spring one (Lutop), and a winter type (LA99). This last cultivar, collected in the USSR (Georgia) was studied for cold resistance at the "INRA Station d'Amélioration des Plantes Fourragères de Lusignan, France" (Papineau, 1987). As other winter ecotypes from central Italy, this lupin presented a better resistance to low temperatures than the spring varieties. So, LA99 was selected for the present study as a potentially resistant cultivar and Lutop, the spring variety, as a presumed sensitive one. The aim of this work was to detect protein(s) which could be used as marker(s) for cold resistance. It was also to improve our understanding of the mechanisms of gene expression involved in metabolic response to low temperatures for the sweet white lupin, a species which could be an important crop for protein-rich seed production in European countries.

\section{MATERIALS AND METHODS}

Seeds of the two varieties (Lutop and LA99) of Lupinus albus $L$, came from INRA (Station de Lusignan, France, which was associated with this work).

\section{Cultures}

Seeds of homogeneous weight (approximately 320 $\mathrm{mg}$ per seed for Lutop and $350 \mathrm{mg}$ for LA99) were surface sterilized in a solution of $\mathrm{Ca}$ hypochloride $(90$ $\mathrm{g} / \mathrm{l} ; 30 \mathrm{~min}$ ) and washed in sterile distilled water. Imbibition was obtained by placing the seeds ( 55 per sample) for $12 \mathrm{~h}$ in sterile water and then in Petri dishes on wet filter paper, in the dark, until germination occurred. Samples were subjected either to $25^{\circ} \mathrm{C}$ (control) or to $5{ }^{\circ} \mathrm{C}$ for different time periods. They were harvested, weighed and stored at $-80^{\circ} \mathrm{C}$. Results were expressed as percentages of the weight of the dry seeds.

Seedlings of similar size (24 h imbibition and $40 \mathrm{~h}$ in Petri dishes at $25^{\circ} \mathrm{C}$ ) were grown in growth chambers $\left(24^{\circ} / 18^{\circ} \mathrm{C}\right.$, day/night; $14 \mathrm{~h} / 10 \mathrm{~h}$, light/dark; 54.4 $\left.\mathrm{mE} \cdot \mathrm{m}^{-2} \cdot \mathrm{s}^{-1}\right)$, in sterile distilled-water moistened vermiculite. Plants with 3-4 leaves were divided into two groups: one was maintained under the same growing conditions, the second was transferred to $5^{\circ} \mathrm{C}(20.4$ $\mathrm{mE} / \mathrm{m}^{2} / \mathrm{s}$ ). Leaves 1 and 4 (development order) and stem apex (apical bud) were harvested after different exposition times at $5^{\circ}$ or $25^{\circ} \mathrm{C}$. Samples were fixed and stored at $-80^{\circ} \mathrm{C}$.

For root studies, 3 homogeneous seed samples (50 seeds each) were imbibed and exposed at $25^{\circ} \mathrm{C}$ for 4 days in Petri dishes. Then, a control was maintained under the same conditions and samples were submitted to $5{ }^{\circ} \mathrm{C}$ for 10,24 and $48 \mathrm{~h}$, and to $0^{\circ} \mathrm{C}$ for 2,10 and $24 \mathrm{~h}$ in total darkness.

\section{HPLC}

Proteins were extracted in $0.05 \mathrm{M}$ Tris- $\mathrm{HCl}$ buffer, $\mathrm{pH}$ 7.5 , containing $8 \mathrm{M}$ urea and 5\% 2-ME. Polypeptides were separated on a Brownlee RP 300 column (4.6 $x$ $250 \mathrm{~mm}$ ) with an acetonitrile gradient, in $80 \mathrm{~min}$ (solvent $A=0.1 \%$ TFA in water: acetonitrile, $88: 12, \mathrm{v} / \mathrm{v}$, solvent $B=0.1 \%$ TFA in water: acetonitrile, 20 : $80, \mathrm{v} / \mathrm{v})$. Temperature was $60^{\circ} \mathrm{C}$ and flow rate $1 \mathrm{ml} /$ min. Detection was with UV at $280 \mathrm{~nm}$ (LKB apparatus). These methods were developed by Burnouf and Bietz (1984) for the study of the reserve proteins of wheat endosperm. The extraction medium as well as the reserve phase wide pore ( $300 \AA$ ) silica gel column used for the polypeptides separation are very powerful (Buehler et al, 1989). About $100 \mu \mathrm{g}$ of proteins were injected for each radicle sample and $200 \mu \mathrm{g}$ for the shoot apice and the leaves.

\section{RESULTS}

\section{Imbibition and germination}

At $25^{\circ} \mathrm{C}$, full imbibition of the seeds of both lupin varieties was practically reached within $24 \mathrm{~h}$ (fig 1). Increase of seed fresh weight was $150 \%$ after $40 \mathrm{~h}$. Imbibition was more rapid for LA99 samples than for those of Lutop during the first hours of water absorption. But this difference disappeared after about $20 \mathrm{~h}$. 




Fig 1. Imbibition of Lutop and LA99 seeds at $25^{\circ} \mathrm{C}$ and $5^{\circ} \mathrm{C}$. The increasing fresh weight of each sample (55 seeds) was expressed as percentages of the weight of the dry seeds (initial dry weight $=0 \%$ ).

Imbibition proceeded more slowly at low temperature: 20 to $25 \mathrm{~h}$ were needed to obtain $100 \%$ increase of fresh weight at $5{ }^{\circ} \mathrm{C}$, compared to only $5-7 \mathrm{~h}$ at $25{ }^{\circ} \mathrm{C}$. $150 \%$ increase in fresh weight was obtained only after $220 \mathrm{~h}$ at $5{ }^{\circ} \mathrm{C}$ (fig 1).

Germination (radicle emergence through the teguments) was obtained at $25^{\circ} \mathrm{C}$ after $24 \mathrm{~h}$ imbibition followed by $24 \mathrm{~h}$ in Petri dishes, on water saturated filter paper. At $5^{\circ} \mathrm{C}, 168 \mathrm{~h}$ in Petri dishes were needed for germination, after imbibition. Initial growth was very slow at $5^{\circ} \mathrm{C}$ (fig 2).

\section{Modifications of protein composition}

\section{Roots}

Plants were grown at $25^{\circ} \mathrm{C}$ during 4 days, then at $5^{\circ}$ or at $0^{\circ} \mathrm{C}$ for various time periods in darkness. Protein compositions of the two controls (Lutop and LA99, at $25^{\circ} \mathrm{C}$ ) were similar but they could be differentiated quantitatively (peaks 10, 11, 25, fig 4). At low temperature some polypeptides were synthesized and some others disappeared.

Effects of low temperature $\left(5^{\circ} \mathrm{C}\right)$ differed greatly between genotypes. In LA99, these effects (fig 3) were revealed essentially by a decrease of peaks 1,2 after $24 \mathrm{~h}$ and an increase of peaks 10,11 after $48 \mathrm{~h}$. On the contrary in Lutop, synthesis was evident for polypeptides 23 , 24,25 after only $10 \mathrm{~h}$ exposure to $5^{\circ} \mathrm{C}$. Later (after 24 and $48 \mathrm{~h}$ ), the relative importance of peak 25 persisted, but increased for peak 3,4 and decreased for 1, 2 (as in LA99).

After exposure to $0^{\circ} \mathrm{C}$, (fig 4), differences between the two varieties were confirmed. Protein composition of LA99 was slightly modified only after $10 \mathrm{~h}: 3$ and 4 peaks were higher than for controls, but 1 and 2 peaks were lower. After $24 \mathrm{~h}$, an important increase of peak 25 and a decrease of peak 3 and 4 was noted. For Lutop, the polypeptide composition varied greatly and rapidly. After $2 \mathrm{~h}$ at $0^{\circ} \mathrm{C}$, many peak heights had increased: $3,4,6,7,23,24,25,32$ but this increase was attenuated for peaks 10,11 . After



Fig 2. Growth of Lutop and LA99 seedlings at $25^{\circ} \mathrm{C}$ and $5^{\circ} \mathrm{C}$. Growth was expressed as increasing length of the radicles $(55$ seeds). 

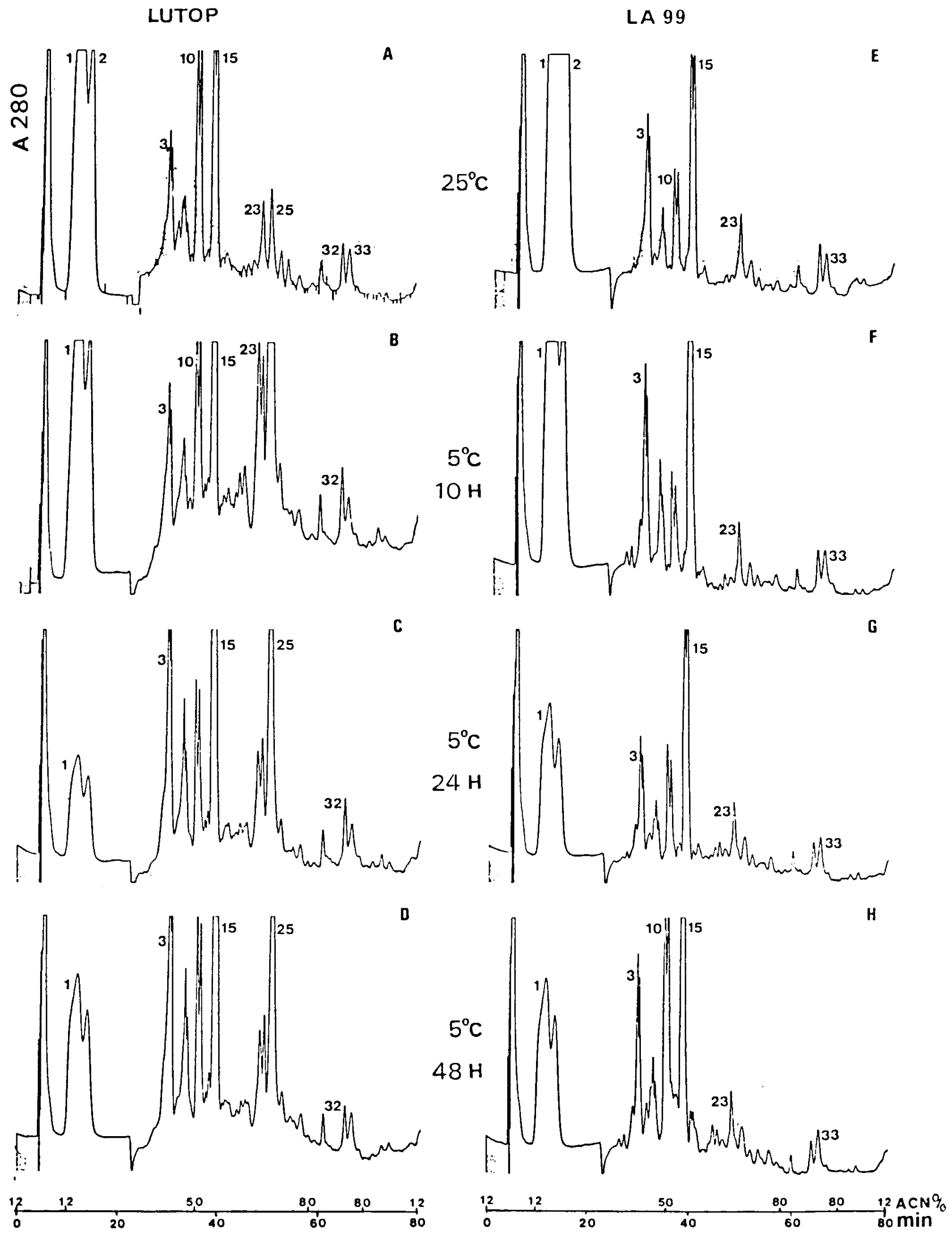

Fig 3. Analysis of root apex proteins of Lutop and LA99 by high performance liquid chromatography (HPLC). Lutop: A: control, 4 days at $25^{\circ} \mathrm{C}, \mathrm{B}, \mathrm{C}, \mathrm{D}: 4$ days at $25^{\circ} \mathrm{C}$ followed by 10,24 or $48 \mathrm{~h}$ at $5^{\circ} \mathrm{C}$, respectively. LA99: E: control, $25^{\circ} \mathrm{C}, \mathrm{F}, \mathrm{G}, \mathrm{H}: 5^{\circ} \mathrm{C}$ : same conditions as for Lutop. Absorbance at $280 \mathrm{~nm}$. 

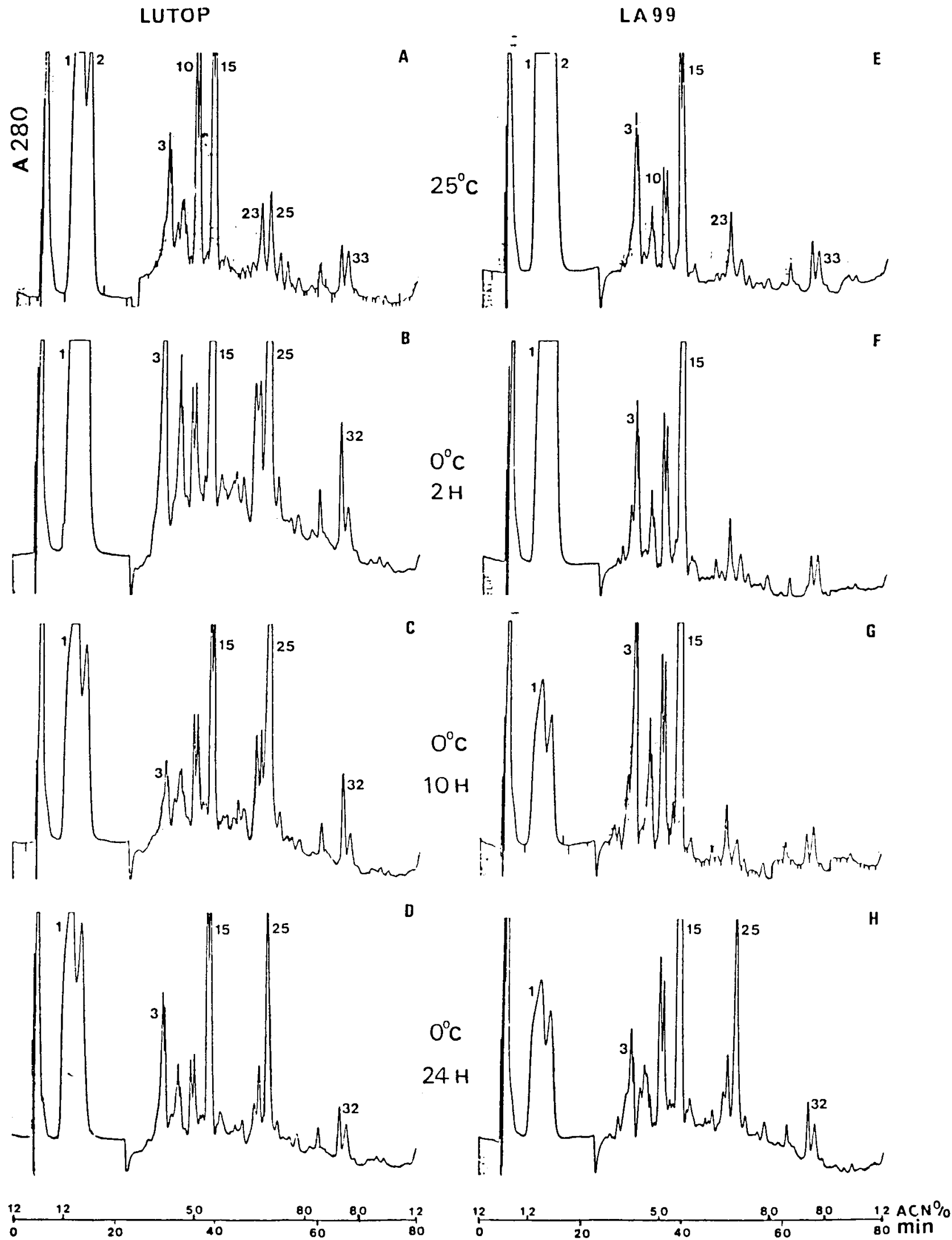

Fig 4. Analysis of root apex proteins of Lutop (A, B, C, D) and LA99 (E, F, G, H) by HPLC. Lutop: A: control: 4 days at $25^{\circ} \mathrm{C}$; $B, C$, $\mathrm{D}: 4$ days at $25^{\circ} \mathrm{C}$ followed by 10,24 , or $48 \mathrm{~h}$ at $0^{\circ} \mathrm{C}$. LA99: $\mathrm{E}$ : control, $25^{\circ} \mathrm{C} ; \mathrm{F}, \mathrm{G}, \mathrm{H}, 0^{\circ} \mathrm{C}$. Absorbance at $280 \mathrm{~nm}$. 
$24 \mathrm{~h}$, this increase of peak 25 was maintained, but surface areas of peaks 10,11 decreased. At this stage, the chromatographic profiles of Lutop and of LA99 were relatively similar, the main difference concerning peaks 10, 11 .

\section{Shoot apices}

Controls for apex extracts from Lutop and from LA99 gave comparable chromatograms (fig 5). After $24 \mathrm{~h}$ at $5^{\circ} \mathrm{C}$, some peak areas $(7,8,9)$ showed an important increase for Lutop. But alterations were limited for LA99, the most impor- tant one concerned peak 17 which was very slight in controls. After 14 days at $5^{\circ} \mathrm{C}$, chromatograms from the two genotypes were more similar, but some differences persisted, essentially for the hydrophilic polypeptides (peaks 3 to 9 and peak 16).

\section{Leaf 4 (fig 6a, b, e, f)}

The polypeptide compositions were very similar in both genotype controls. However, higher relative concentration of the proteins eluted in peaks 1 and 2 of the Lutop variety could be noted. After
LUTOP
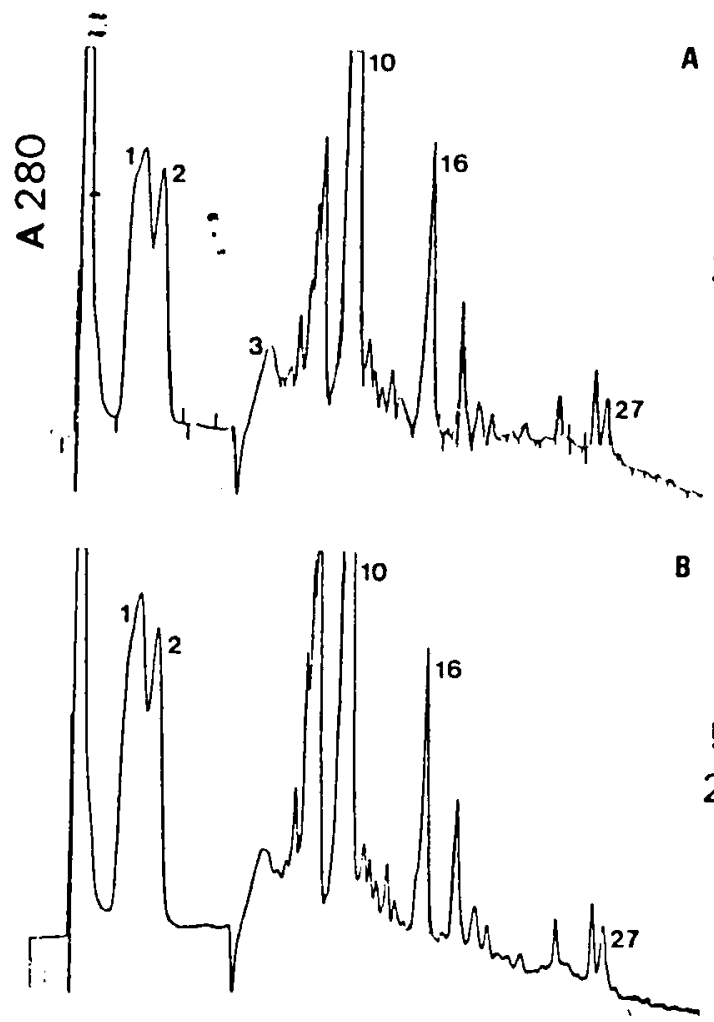

B

A

$25^{\circ} \mathrm{C}$



$5^{\circ} \mathrm{C}$

$24 \mathrm{H}$
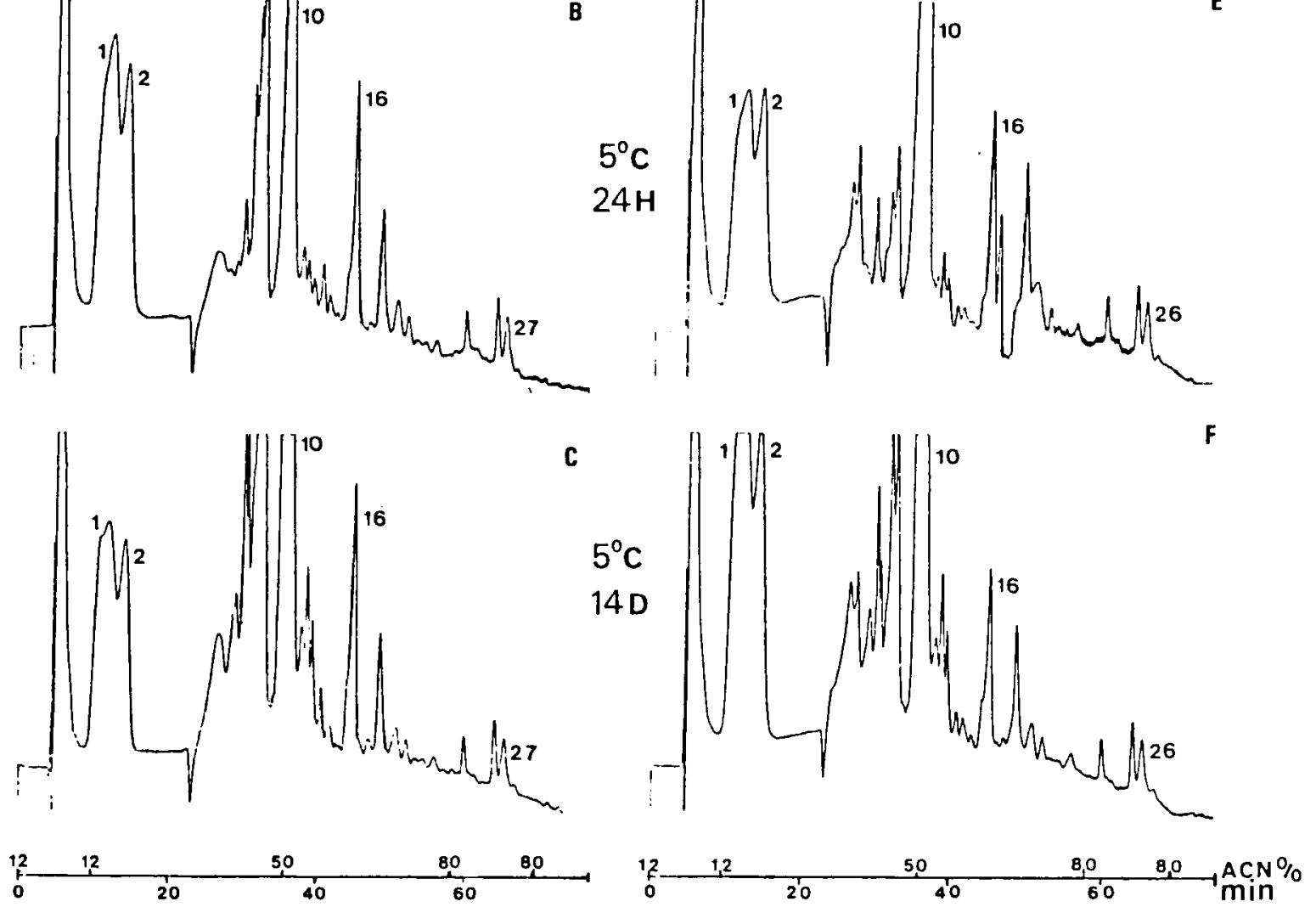

Fig 5. Analysis of shoot apex proteins of Lutop (A, B, C) and LA99 (D, E, F) by HPLC. Samples were grown at $25^{\circ} \mathrm{C}$ during 14 days and exposed to $5^{\circ} \mathrm{C}$ for $24 \mathrm{~h}$ or for 14 days. Absorbance at $280 \mathrm{~nm}$. 
14 days at $5^{\circ} \mathrm{C}$, the chromatogram for LA99 extract was not greatly modified (peaks 1,2 decreased, 7 increased) but for Lutop, peaks 8 and 9 increased.

\section{Leaf 1 (fig $6 c, d, g, h$ )}

The protein compositions of the controls were once more very similar in both lupins. Surprisingly, modifications of polypeptide compositions by low temperatures $\left(14\right.$ days at $5^{\circ} \mathrm{C}$ ) were inverted compared to those described for the other organs. Indeed, for this leaf, the oldest one, the most important alterations were obtained for LA99 extracts. These alterations concerned peaks 5 to 9 (relatively hydrophilic polypeptides) and 19, 20 (more hydrophobic). For Lutop samples, peaks 4 to 6 (hydrophilic) were the most affected ones. The appearance of a new peak (31), missing in controls, should also be noted.

\section{DISCUSSION}

Imbibition and germination were studied only to obtain some morphological data indicating the effects of low temperatures on the lupin seeds development.

Imbibition of white lupin seeds (cultivar Kalina) has been previously studied (Le Deunff et al, 1989). Water uptake was different for soaked seeds or for seeds imbibed on a moistened support, as for the different parts of the seed (teguments, cotyledons, axis), the axis absorbed more rapidly. Moreover, the rate of water uptake was higher when the different seed compartments were hydrated separately. Compared to the present results obtained for Lutop and LA99 genotypes, water penetration in the "Kalina" seeds proceeded apparently more rapidly (at 20 $25^{\circ} \mathrm{C}$ ).

For Lutop and LA99 genotypes, seed imbibition differed under normal growing temperature $\left(25^{\circ} \mathrm{C}\right)$ and under low temperature conditions $\left(5^{\circ} \mathrm{C}\right)$. For the soybean, the highest low temperature sensitivity appeared during seed imbibition and germination was reduced when imbibition proceeded at $12-14{ }^{\circ} \mathrm{C}$ (Bramlage et al, 1978; Hobbs and Obendorf, 1978). For the lupin, germination percentage was reduced for the Lutop variety at low temperature: $5 \%$ of the seeds did not germinate at $5{ }^{\circ} \mathrm{C}$. Seed exposure at $5^{\circ} \mathrm{C}$ resulted in an increase of the duration (4 times) needed for germination. Seeds from truly chilling sen- sitive plants do not germinate below $10^{\circ} \mathrm{C}$. Seeds from chilling resistant species are able to germinate under the same conditions, but germination rate may be slow and germination percentage may decrease (Herner, 1986). Moreover, the plasma membrane reorganization that occurred during water uptake by the seeds during imbibition is delayed by low temperatures (Bramlage et al, 1978). More injury (electrolyte leakage, necrosis at the radicle tip, damage to the root cortex) could occur if imbibition is accomplished under low temperatures (Bramlage et al, 1978). It is also well known that low soil temperatures decreased highly the water absorption by herbaceous plants (Chen et al, 1983). Thus, owing to their different imbibition and germination behaviours, even the more sensitive genotype of white lupin studied here possesses only a relative sensitivity to the low $\left(5^{\circ} \mathrm{C}\right)$ temperature applied, compared to other plants such as soybean.

At the protein composition level, exposure of plants to low temperatures has been shown to induce alterations in protein metabolism (Guy et al, 1985; Meza-Basso et al, 1986; Mohapatra et al, 1987a, b, 1988). The development of cold hardening is also correlated to changes in the levels of translatable mRNA (Meza-Basso et al, 1986; Mohapatra et al, 1987a; Gilmour et al, 1988). It was proposed that low temperature could induce the expression of some genes (Schaffer and Fisher, 1988). The proteins synthesized appear to be specific to cold induced stress. Some are related to photosynthesis. Indeed, quantitative increases in the levels of RuBP carboxylase and fructose BP phosphatase appear to enable plants to maintain a sufficient photosynthetic rate at low temperature (Berry and Raison, 1981). Cold treatment also induced an increased synthesis of several membrane proteins (Yoshida and Uemura, 1984; Yoshida, 1984; Mohapatra et al, 1988).

Alterations of the protein composition of the two lupin genotypes were recorded for roots, shoot apices and leaves. Some proteins were synthesized (cold induced proteins), whereas some others disappeared (cold repressed proteins). These alterations of protein metabolism were obtained at $5{ }^{\circ} \mathrm{C}$, a temperature generally considered as related to conditions of coldhardening (Guy, 1990). At $0^{\circ} \mathrm{C}$, stronger damage is often observed, but for the two lupins studied, protein composition of the roots was not dramatically modified during the first $24 \mathrm{~h}$ of cold exposure. Under these conditions, alterations in 



Fig 6. Analysis of leaf $4(F 4)$ and leaf $1(F 1)$ proteins of Lutop (A, B, C, D) and LA99) (E, F, G, H) by HPLC. Plants were grown at $25^{\circ} \mathrm{C}$ during 14 days and exposed to $5^{\circ} \mathrm{C}$ for $24 \mathrm{~h}$ or for 14 days. Absorbance at $280 \mathrm{~nm}$. 
chromatographic profiles appeared more rapidly and were more important for the spring variety. These results confirm that roots have great capacities to acclimate to chilling temperature (Markhart, 1986). They also show that it is probably more the sensitivity of the plant to cold which induces metabolic adaptation rather than its resistance. The results indicate other features: roots, shoot apices and young leaves (ie young growing tissues) present the same type of response in protein pattern alterations during cold exposure, ie a more important reaction in the spring variety. On the contrary, older leaves show greater alterations in the winter genotype. Thus, for the white lupin, metabolic responses of the plants to low temperature are highly dependant on organ type and on the physiological state of a given organ.

The results reported in this study indicate that the spring variety Lutop of the white lupin is more sensitive to the low temperatures. When these conditions were applied to the plant, its protein composition presented more modifications than that of the winter variety LA99. The greatest resistance of this last type is reflected by its greater metabolic stability. The modifications of protein composition that appeared for Lutop probably indicate part of the metabolic adaptations that could be implicated in the chilling acclimation processes of this variety.

It should also be noted that HPLC is a very convenient method for investigating very small alterations in protein metabolism that usually require the use of labelled compounds. This technique could be used to identify proteins specific of cold hardening or cold resistance. Studies are in progress in our laboratory to isolate such markers.

\section{ACKNOWLEDGMENTS}

The authors are very grateful to A Cloarec for her help in the preparation of the English version of the text. They thank M Lasbley and $C$ Rousset for excellent assitance in manuscript preparation.

\section{REFERENCES}

Berry JA, Bjorkman O (1980) Photosynthetic response and adaptation to temperature in higher plants. Annu Rev Plant Physiol, 31, 491-543

Berry JA, Raison JK (1981) Responses of macrophytes to temperature. In: Physiological Plant Ecology 1. Responses to the Physical Environment Encyclo- pedia of Plant Physiology. New Series, vol $12 \mathrm{~A}$ (Lange OL, Nobel PS, Osmond CB, Ziegler H, eds) Springer-Verlag, Berlin, 277-339

Bramlage WJ, Leopold AC, Parrish DJ (1978) Chilling stress to soybeans during imbibition. Plant Physiol $61,525-529$

Buehler RE, Vantoai TT, Mc Donald MB Jr (1989) The optimisation of elution and extraction conditions for the separation of soybean seed proteins using RPHPLC. Seed Sci Technol, 17, 193-204

Burnouf T, Bietz JA (1984) Reversed-phase highperformance liquid chromatography of reduced glutenin, a disulfide-bonded protein of wheat endosperm. J Chromaogr, 299, 185-199

Carter JV, Brenner ML (1985) Plant growth regulators and low temperature stress. In: Hormonal Regulation of Development. III. Role of Environmental Factors (Pharis RP, Reid DM, eds) SpringerVerlag, Berlin, Heidelberg, New-York, Tokyo, 418443

Chen THH, Gusta VL, Fowler DB (1983) Freezing injury and root development in winter cereals. Plant Physiol 73, 773-777

Cloutier $V$ (1983) Changes in the electrophoretic patterns of the soluble proteins of winter wheat and rye following cold acclimation and desiccation stress. Plant Physiol 71, 400-403

Fowler DB, Dvorak J, Gusta LV (1977) Comparative cold hardiness of several Triticum species and Secale cereale L. Crop Sci 17, 941-943

Gilmour SJ, Hajela RK, Thomashow MF (1988) Cold acclimation in Arabidopsis thaliana. Plant Physiol 87, 745-750

Graham D, Patterson BD (1982) Responses of plants to low nonfreezing temperatures: protein metabolism and acclimation. Annu Rev Plant Physiol 33, 347-372

Guy CL (1990) Cold acclimation and freezing stress tolerance role of protein metabolism. Annu Rev Plant Physiol 41, 187-223

Guy CL, Niemi KJ, Brambl R (1985) Altered gene expression during cold acclimation of spinach. Proc Natl Acad Sci USA 82, 3673-3677

Herner RC (1986) Germination under cold soil conditions. Hortscience 21, 1118-1122

Hobbs PR, Obendorf RL (1978) Interaction of initial seed moisture and imbibitional temperature on germination and productivity of soybean. Crop Sci 12, 664-667

Kacperska-Palacz A, Dlugokecka E, Breitenwald J, Wcislinska B (1977) Physiological mechanisms of frost tolerance: possible role of protein in plant adaptation to cold. Biol Plant 19, 10-17

Le Deunff Y, Ballot S, Touboul C (1989) Hydratation des graines de lupin blanc et relargage des électrolytes. Seed Sci Technol 17, 325-340

Levitt J (1980) Responses of Plants of Environmental Stresses. Vol I. Academic Press, New York, London, $497 \mathrm{pp}$ 
Lin C, Guo WW, Everson E, Thomashow F (1990) Cold acclimation in Arabidopsis and wheat. A response associated with expression of related genes encoding "boiling-stable" polypeptides. Plant Physiol 94, 1078-1083

Markhart AH (1986) Chilling injury: a review of possible causes. Hortscience 21, 1329-1333

Meza-Basso L, Alberdi M, Raynal M, FerreroCardinanos ML, Delseny M (1986) Changes in protein synthesis in rapeseed (Brassica napus) seedlings during a low temperature treatment. Plant Physiol 82, 733-738

Mohapatra SS, Poole RJ, Dhinsa RS (1987a) Changes in proteins and translatable mRNA populations during cold acclimation of alfalfa. Plant Physiol 84, $1172-1176$

Mohapatra SS, Dhinsa RJ, Poole RJ (1987b) Changes in gene expression during cold acclimation of alfalfa. Plant Physiol 83, S-156

Mohapatra SS, Poole RJ, Dhindsa RS (1988) Abscisic acid-regulated gene expression in relation to freezing tolerance in alfalfa. Plant Physiol 87, 468-473

Mohapatra SS, Wolfraim L, Poole RJ, Dhindsa RS (1989) Molecular cloning and relationship to freezing tolerance of cold acclimation-specific genes in alfalfa. Plant Physiol 89, 375-380

Papineau J (1987) La résistance au froid des lupins blancs (Lupinus albus L). Variabilité génétique, sélection, création de matériel végétal doux. Mémoire d'Ingénieur d'État, Spécialité Amélioration des Plantes. École Supérieure Agronomique de Montpellier, France, $68 p$

Sarhan F, D'Aoust MJ (1975) RNA synthesis in spring and winter wheat during cold acclimation. Physiol Plant 35, 62-65
Sarhan F, Chevrier N (1985) Regulation of RNA synthesis by DNA-dependant RNA polymerases and RNases during cold acclimation in winter (Triticum aestivum cultivar Talbot) and spring wheat (Ta cultivar Glenlea). Plant Physiol 78, 250-255

Schaffer MA, Fischer RL (1988) Analysis of mRNA that accumulate in response to low temperature identifies a thiol protease gene in tomato. Plant Physiol 87, 431-436

Steponkus PL (1981) Responses to extreme temperatures. Cellular and sub-cellular bases. In: Encyclopedia of Plant Physiol, New Series, Vol. 12 A. Physiol Plant Ecology (Lange OL, Nobel PS, Osmond $\mathrm{CB}$, Ziegler $\mathrm{H}$, eds) Springer-Verlag, Berlin, 371402

Stewart RRC, Bewley JD (1981) Protein synthesis and phospholipids in soybean axes in response to imbibitional chilling. Plant Physiol 68, 516-518

Voinikov VK, Koritov MV, Kalacheva EA (1989) Lowtemperature induction of stress protein synthesis in plants. Fiziol Rast 36, 107-111

Weiser CJ (1970) Cold resistance and injury in woody plants. Science 169, 1269-1278

Wu CH, Warren HL, Staraman K, Tsai CV (1988) Translational alterations in maize leaves responding to pathogen infection, paraquat treatment, or heat shock. Plant Physiol 86, 1323-1329

Yoshida S (1984) Chemical and biophysical changes in the plasma membrane during cold acclimation of mulberry bark cells (Morus bombycis Koidz cv Goroji). Plant Physiol 76, 257-265

Yoshida S, Uemura M (1984) Protein and lipid compositions of isolated plasma-membranes from orchard grass (Dactylis glomerata L) and changes during cold acclimation. Plant Physiol 75, 31-37 